\title{
Broadcast Journalism of Private Radio in Cirebon, Indonesia, in the Convergence Era
}

\author{
Afiaty Fajriyah Ningrum, Justito Adiprasetio
}

Universitas Padjadjaran, Indonesia

\begin{abstract}
Convergence is a deep integration of knowledge, tools, and all relevant areas of human activities. As an inevitable condition, convergence has also changed a lot of aspects of mass media at the international, national, and local levels. This study elaborates how the local radios in Cirebon, namely Sindangkasih FM, Suara Gratia FM, and Cirebon Radio, are adapting to the convergence culture. This study seeks to demonstrate how the convergence culture can affect private broadcast media, which are not in the epicentrum of media in Indonesia. This study indicates that these three private radios in Cirebon have tried to adapt to the convergence culture in minimally three aspects, namely structural, information coverage, and news presentation or storytelling convergence. The structural convergence happened at the organizational structure of the radio, in which more direct and fluid coordination in the newsgathering and writing processes is applied. At the news coverage level, reporters and scriptwriters are responsible for managing news content for old radio broadcasts and new online media as well. At the news presentation level, the news is not only broadcasted but also reported on new online channels, such as websites and social media. These convergences have further created a more convergent newsroom, including integrating journalism workflows, applying multiskilled journalism and resource sharing, using various technological tools, creating interactivity with the audience, and expanding the audience reach.
\end{abstract}

Keywords: journalism, convergence, broadcasting, interactivity, radio.

\section{Article History}

Received: 5 August 2021

Revised: 27 October 2021

Accepted: 5 November 2021

\section{Introduction}

Communication scholars have echoed the term convergence since the technological developments in the last two decades. Convergence is the tendency of different initially unrelated technologies to become more integrated as they develop and progress, for example, the combination of video, telecommunications, and computer technologies (Adiprasetio \& 
Wibowo, 2020). Convergence allows people to answer questions in the framework of accelerating competencies and new technologies (Roco, 2002). This phenomenon has been assessed as an unavoidable condition and prone to consequences or disruption to humans (Silverstone, 1995). Convergence as an inevitable condition disrupts mass media in the international, national, and even forces media with smaller localities to adapt (Ningrum \& Adiprasetio, 2021). This study elaborates how the convergence culture has eventually affected three local broadcasting radios in Cirebon, Indonesia, namely Sindangkasih FM, Suara Gratia FM, and Cirebon Radio. This study seeks to demonstrate how private broadcast media that are not classified as major in Indonesia can also be affected by the convergence culture.

Radio is now making podcasts or other digital streaming devices (Fadilah et al., 2017). They are integrating the radio technology and the internet as a strategy for reinventing, anticipation (Harliantara, 2016, 2019), adaptation (Rachmaria \& Dewi, 2018; Trinoviana, 2017), and resilience in especially carrying out the journalism functions (Harliantara, 2019). Private radio in Cirebon is no exception. Cirebon is one of the largest cities in West Java, which has a comparative advantage, has become a vital media investment area, and has become a member of the Indonesian National Private Broadcasting Radio Association (PRSSNI). In West Java, Cirebon is in the 2nd position with the highest growth rate in the number of radios after Bandung, namely 13 radio broadcasts (PRSSNI, 2017).

But even so, Cirebon has not become the focus of research on the study of mass media in Indonesia, especially for the journalistic aspect. So far, previous studies on mass media in Indonesia have only focused on big cities on a national scale, such as Jakarta, Medan, Makassar, Surabaya, Semarang, Jogja, Bandung, Denpasar, Palembang, and Surakarta (PRSSNI, 2015). As a result, academic literature about other cities in Indonesia is very limited. Previous studies on journalism, especially in radio broadcasting in Cirebon, have focused on one medium (Ningrum \& Adiprasetio, 2021) and therefore lack a comprehensive description. From such background situations, this research will answer the following question: how do the private radio stations in Cirebon adapt their journalism practice in the era of convergence?

As analytical tools, this paper applies several convergence notions. First, the idea of journalistic convergence (Gordon, 2003) would be used to explain the scope of journalistic convergence that occurs in the newsroom of private radio broadcasting in Cirebon. Second, the idea of the main roles in the convergent newsroom (Fisher, 2007) is good to explain the role of each position in the organizational structure in editorial activities in private radio broadcasting in Cirebon. Third, the concept of interactivity (Pavlik, 2001) is used to describe the interactivities occurring in the practice of broadcast journalism in private radio in Cirebon. 


\section{Method}

This research has applied a case study method due to several considerations, i.e., the type of research question, the control the researcher has over the events and behaviors to be studied, and the focus of the research phenomenon. First, the research question of this paper is explanatory, dealing with operational links that require separate time tracking and not just frequency of occurrence. Second, researchers have the opportunity to control events through systematic observation and interviews. Third, this research tracks contemporary events (Yin, 2006).

The empirical data were collected through documentation, interviews, and observations. The documents that have been used in this research are official documents, i.e. internal documents belonging to Sindangkasih FM, Suara Gratia FM, and Cirebon Radio, as well as external documents belonging to broadcasting associations in West Java. Interviews were an essential source of information for this study. It has applied open-ended interviews, allowing the researchers to ask key informants about the facts of an event in addition to their opinions about the events. Open-ended interviews were conducted with key informants responsible for the managerial levels of private radio stations in Cirebon, namely the program director or station manager. The interviews were also performed with the reporters and scriptwriters. The observations were carried out by directly visiting the object of this study, namely Sindangkasih FM, Suara Gratia FM, and Cirebon Radio, and especially observing the production and distribution of the radio content within specific periods.

\section{Convergence culture, radio and journalism}

Many scholars have argued that convergence is not a new thing encountered by humans. Convergence has occurred since the invention of the post, the telephone, the telegraph, and the mass communication media (printing machines, the radio, and television). In each of these technologies, there is always a process of blurring boundaries or integrating various fields (convergence of modes) in the practice of production, distribution, and consumption (Jenkins, 2001, 2008; Sacco, 2016).

This decade's expansion of new media resources has led to what Benkler (2006) describes as a 'hybrid media ecology'. In such media ecology, commercial, amateur, government, non-profit, education, activist, and other agencies interact in many ways in the media industry, both in terms of formats and channels (Adiprasetio \& Wibowo, 2020). This 
interaction encourages changes in the production and distribution of content, and new meeting rooms for each group as well. Changes aim to pursue their own goals while still shaping the total media environment (Jenkins, 2001, 2008).

Within the radio industry, the expansion has been seen in different parts of the world in various styles and ways. The expansion of the radio broadcasting industry due to technology has been shown, among others, by the development of transmedia radio storytelling content and the Hackney Hear iPhone application in the United States, Canada, and Australia (Edmond, 2015); development of talkback programming in Australia in the 1990s via on-site, audio streaming services with web-cam images (Gould, 2009); development of digital radio in Australia and America through L-band transmission (Berryman, 1999); development of streaming or podcasting services on the web as well as iOS applications to listen to traditional North American music radio broadcast content (Cwynar, 2017); development of the iPod as a new method to distribute the conventional radio broadcast (Berry, 2006); independent audio podcasting development (Markman, 2012), and others.

Likewise, in Indonesia, the expansion of new media has also occurred massively and sporadically. The visible development of new media includes the provision of streaming and podcasting services on websites and audience interaction through social media (Harliantara, 2016); Youtube distribution of conventional broadcast content (Rachmaria \& Dewi, 2018); streaming services on websites, integration of community radio networks and private broadcast radio, integration with television and online media, integration of on-air and off-air activities (Panuju, 2018); utilization of websites, social media, and applications (Trinoviana, 2017).

Convergence can ultimately be described as a process that works across media (Hacklin et al., 2013; Hess \& Matt, 2013; Jenkins, 2008). Convergence describes communication processes in which two or more media platforms are involved in an integrated manner. This cross-media production occurs in all areas of the news industry and has implications for most news workers (Adiprasetio \& Wibowo, 2020; Spyridou \& Veglis, 2016). This phenomenon affects the working conditions of daily reporting, journalistic hierarchies, authorship, and journalists' control over their reporting.

Convergence culture has also disrupted journalism in various ways, in previously unimaginable aspects. But to date, most of the world's literature has tended to focus on the adverse developments of convergence that degrade the quality of journalism, because of the bottleneck of the online economy, the advertising crisis, job insecurity, and the decline in the print market. However, journalism is increasingly adapting to this new environment, defined by the converging nature of media liaisons. This process is still in progress and tends to be less accelerated compared to other media convergence cultures because changes in journalism are 
more than just implementing new practices in journalism work (Jenkins, 2008; Kaltenbrunner \& Meier, 2013). The shift from a traditional print or broadcast culture that has had strong cultural foundations, professional norms, and established routines for decades to a culture in which distinct boundaries and categories tend to blur or disappear is a huge challenge (Jenkins, 2001, 2008; Menke et al., 2018; Quandt \& Singer, 2009).

Social media and web 2.0 are two elements of new media technology that greatly influence the relationship between professional journalism and interactive audiences (Jenkins, 2001; Quandt \& Singer, 2009). At first, academics tended to focus on aspects of technological innovation and reduce the convergent relationship as simply a merger between several previously separate fields, such as computerization of journalism, integration of telecommunications aspects with journalism, and the application of digital broadcasting technology (Hess \& Matt, 2013; Kaltenbrunner \& Meier, 2013). However, with the growing understanding of cultural influences on the establishment of the convergence of journalism, where the role of the market becomes prominent, content production and reception of convergence that does not generally apply in all places, the attention of media scholars shifts. Emphasis on technology is considered unable to capture socially driven interrelationships in media practices, especially journalism (Menke et al., 2018; Quandt \& Singer, 2009).

To understand the dynamics of the convergence of journalism, it is necessary to recognize that convergence is not only a specific way of producing and distributing news but also reconfiguring culture in the newsroom based on strategies that facilitate or hinder its implementation. Such cultural aspects make the convergence strategy closely related to the newsroom's culture, which determines the realization of convergent journalism. Jenkins (2008) has claimed that convergence represents cultural change across society that affects audiences, media, and companies. Erdal (2009) also advocated the relationship between journalism and convergence and problematized an issue when a convergence strategy meets a network of inter-organizational subcultures. However, instead of the convergence cultureshaping news production, it posits the opposite causality, according to which the existing culture of journalism shapes the practice of convergence. It will be further complicated by the fact that newsroom culture is not static, but constantly evolving. Experience with convergence in newsrooms is continuously incorporated into strategic decision-making in its development process. It forms the basis for media managers' next steps towards broader adoption of convergence in newsrooms.

Predictions of many scholars about conventional broadcasting that radio broadcasting will be buried, sticking out along with the growth of new media. The presence of the internet as a medium with a high penetration rate after television and outdoor media indicates that Indonesian people are increasingly fond of accessing content through new media (Harliantara, 
2019). This drives radio to not only adapt but also build a convergent culture within it. Radio is not only trying to implement multi-channel publications or what is often referred to as 'multi-platform', but is slowly implementing what Jenkins (2001) calls 'transmedia', what Rajewsky (2002) calls 'intermodality', or described by Thomasen (2007) as 'cross-media'. Thomasen (2007) sees cross-media as an extension of multi-platform. Multi-platform denotes the use of more than one media platform in the same communicative situation, but without any communicative relationship or reference between them. Cross-media is an extension where the link or reference is present in the communication.

\section{The adaptations of journalistic practices}

To maintain its existence in the ever-changing media ecosystem, private radio carries out several reinventing or anticipatory steps (Harliantara, 2016) and adaptations (Rachmaria \& Dewi, 2018; Trinoviana, 2017). This research has found two important aspects of journalistic adaptations, namely editorship and human resource management.

\section{a. Editorship}

Sindangkasih FM in the pre-convergence era presented local news about culture, cuisine, and light information about situations or events in the Cirebon area. The news is presented in a live report or news insert known as Cirebon dalam Berita. The selected stories are the result of the reporter's coordination with the program director. In the meeting, reporters or program directors convey projections or plans for coverage as well as topics to be raised on news programs. Reporters travel around the area of their responsibility to cover situations or events that have been projected in the prior coordination or that were not projected but have high news values. The results were processed and compiled into news scripts, either in the form of insert news or live reports, and reported to the program director. In the production room, news materials in the form of scripts are read and recorded to be further combined with the materials in audio formats, such as the interviews with informants.

In the era of convergence, Sindangkasih FM radio broadcasts news with the same theme, namely about culture, culinary, and light information about situations or events in the Cirebon area, as well as national and international news. The news is presented in a program known as Liputan 12, obtained from other sources, namely from mass media networks or online sources. For local news, the scriptwriter picks up information from 
Kabarcirebon.com., a print and online media company that collaborates with Sindangkasih. While for national and international news, the scriptwriter sees and selects five news stories from some news portals to be broadcast on-air and streaming on the Radio Sindangkasih Cirebon application. Selected information is summarized and composed into a radio news script by a scriptwriter, and the results are submitted to the production department. The result is presented in the form of spot news on on-air programs.

In the pre-convergence era, Suara Gratia FM presented Halo Cirebon spot news in the form of local, national, and international news from other mass media. In this program, news from local and national print media is reported back in radio news by broadcasters. Suara Gratia FM also presented a live report and news relay from KBR 68 Jakarta. Reporters carried out live reports to inform light information about the situation or events in the Cirebon area. Reports were made by telephone to the broadcast room during an on-air program. As for the national and international news, they were news relays from KBR 68 Jakarta.

Likewise, in the era of convergence, Suara Gratia FM radio still presents the same news program. However, broadcasters obtain news not only from Rakyat Cirebon and Fajar Cirebon, but also from online sources, such as online news and official websites. For the live report, the reporter reports the news during on-air activities via calling service on the WhatsApp application. After that, the reporter returned to the office to write and publish the news on the Suara Gratia FM website and promote it on Suara Gratia FM social media accounts, such as Facebook, Twitter, and Instagram.

Cirebon Radio presented local news about human interest, government, politics, or culture in the pre-convergent era. Local news was packaged in various forms, ranging from package news in Jurnal Cirebon or Berita Cirebon, insert news in Info Cirebon, and live reports. The primary news sources were the reporters of Cirebon Radio. At first, reporters attend the editorial meeting with the news director to convey projections or coverage plans, topics to be raised, and tasks allocations. After that, reporters conduct interviews and observations in their respective areas to cover situations or events that have been discussed at the editorial meeting. The results are processed and compiled into news scripts, either in the form of taping or live reports with the news director.

As for the convergent era, Cirebon Radio presents local news from their reporters in the form of package news on Berita Cirebon Radio. Before the field coverage, reporters should coordinate the news projections with the program director through direct coordination or online messaging applications. In the field, reporters should conduct interviews, observations, also take photographs. After finishing the data collection, 
reporters return to the office to process the gathered news materials during one day. After that, the materials will be broadcast by the next day on the on-air programs and website of Cirebon Radio.

\section{b. Human resource management}

In the pre-convergence era, the program director of Sindangkasih $F M$ radio was assisted in producing news programs by some reporters covering the Cirebon area. Reporters were targeted to submit five local news stories in a day to the program director. They were also tasked with composing news scripts for live reports and processing and packaging reports for insert news. In processing insert news, reporters collaborate with scriptwriters and producers. Scriptwriter manages news material into news scripts, while producer converts scripts into audio form through recording, editing, and mixing in the production room.

In the era of convergence, to broadcast information in the form of spot news, the program director of Sindangkasih FM radio is assisted by a scriptwriter who is collecting news from local and national online media, selecting them, also deciding five news to be reported. The selected news is summarized and submitted to the producer in the production department to be packaged into radio news.

Broadcasters and reporters supported the Suara Gratia FM station manager to produce news in the pre-convergence era. Broadcasters were responsible for filtering, selecting, and reading the news from the local Cirebon newspaper. They were also responsible for broadcasting news relays from KBR 68 Jakarta. At the same time, the reporters were responsible for news in the form of live reports. It has not changed in the convergence era; broadcasters and reporters manage the program. Hosts manage spot news, while reporters manage live reports and news on website channels. Reporters must put the results of their live reports in online news or articles on the website. He is also responsible for promoting the news on social media.

In the pre-convergence era, the Cirebon Radio program director was supported by a news director and assisted by several reporters. The news director assigned the reporters to cover the news within the Cirebon area. In addition, some of them will alternately be assigned as scriptwriters to write news scripts that will be broadcast later. The news director was responsible for packaging news scripts into audio form through the production process, namely recording, editing, and mixing.

In the convergent era, the organizational structure of Cirebon Radio continues to change. In terms of quantity, there has been a decrease in the quantity of staff of Cirebon Radio. In the news organization structure, for example, news programs that were 
previously managed by a news director with the help of some reporters are now directly handled by reporters responsible for finding news to be broadcast on the news programs. After doing the coverage, the reporters have to proceed with the materials through recording, editing and mixing as news directors did in the pre-convergent era. In addition, reporters are also responsible for filling out news content on the website channel.

\section{The convergent journalism in private radio in Cirebon}

Gordon (2003) has divided journalistic convergence into five dimensions: ownership, tactical, structural, information coverage, and news presentation or storytelling convergence. Ownership convergence refers to a large media company with various platforms for content distribution, including newspapers, television, radio, and online media, to allow crosspromotion in other media that are still under one holding. Tactical convergence is related to cooperation in the use of shared content between companies of different ownership. Structural convergence refers to the management of news coverage and distribution. The convergence of information coverage demands journalists to have various skills that are not only related to journalism but also multimedia expertise. Convergence of news presentation or storytelling occurs at the operational level of journalistic practices with the support of combined equipment such as computers, portable equipment, and the interactive potential of websites and television.

This chapter will discuss three of these five levels of convergence, namely structural, information coverage, and news presentation or storytelling convergence, which occur in Sindangkasih FM, Suara Gratia FM, and Cirebon Radio.

\section{a. News coverage and presentation convergence}

The editorship adaptations show the implications of media convergence on the journalism practices in the private radio stations in Cirebon. The convergence journalistic processes have involved journalists working in several mediums or formats to provide diverse content for different audiences (Dewi, 2012). In the newsroom of Sindangkasih FM, Suara Gratia FM, and Cirebon Radio, the workflow is carried out to produce radio news and online news as well. The reporter or scriptwriter is not only responsible for the production and distribution of terrestrial radio news, but also the production and distribution of news in the new media platform of each radio station. Before reporting activities, the reporter or scriptwriter and the program director or station manager plan to find out and decide 
issues. In reporting activities, reporters or scriptwriters will seek, collect, or select facts either directly in the field or sourced from other mass media. In the next step, the reporter or scriptwriter composes the script based on the information gathered and processed through recording, editing, and mixing for radio programs or writing and uploading on online channels. For online channels such as websites and social media, reporters or scriptwriters need to prepare and process images to complete the news. Lastly, the radio news that has been composed is also distributed to website channels and social media.

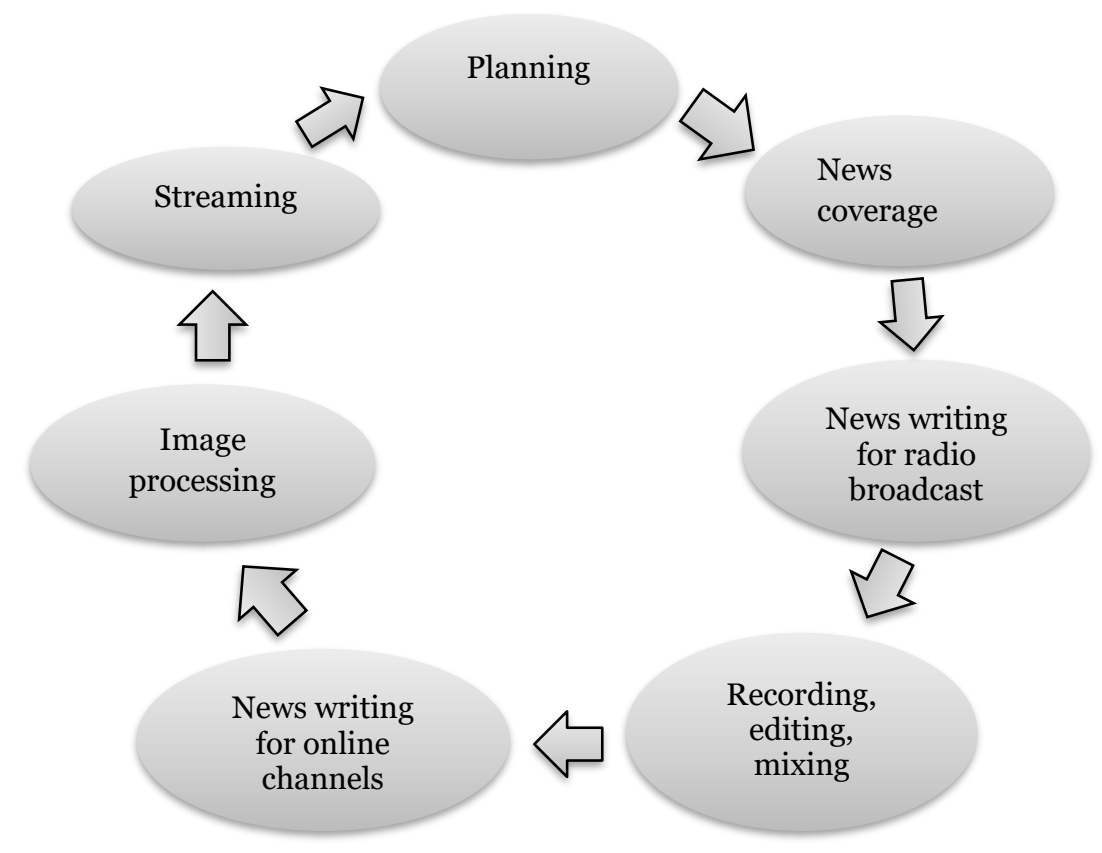

Figure 1. A convergent newsroom of private radio in Cirebon

Such a convergent newsroom requires shared content for various platforms, which is carried out through a database that can be accessed by all staff who need the contents (Dewi, 2012). In Sindangkasih FM, Suara Gratia FM, and Cirebon Radio, news materials, including the news gathered by the reporters from their daily news coverage, are not only used for terrestrial broadcasts but are also used for new online channels. At first, the reporter should proceed with the materials in radio news format. After completing that, they should proceed with the same content for the website and social media, complete with visual materials. This kind of convergent newsroom aims to provide content for various channels by fully integrating news streams for print to digital versions, from planning to production. In this model, every person is responsible for all channels (Dewi, 2012). 


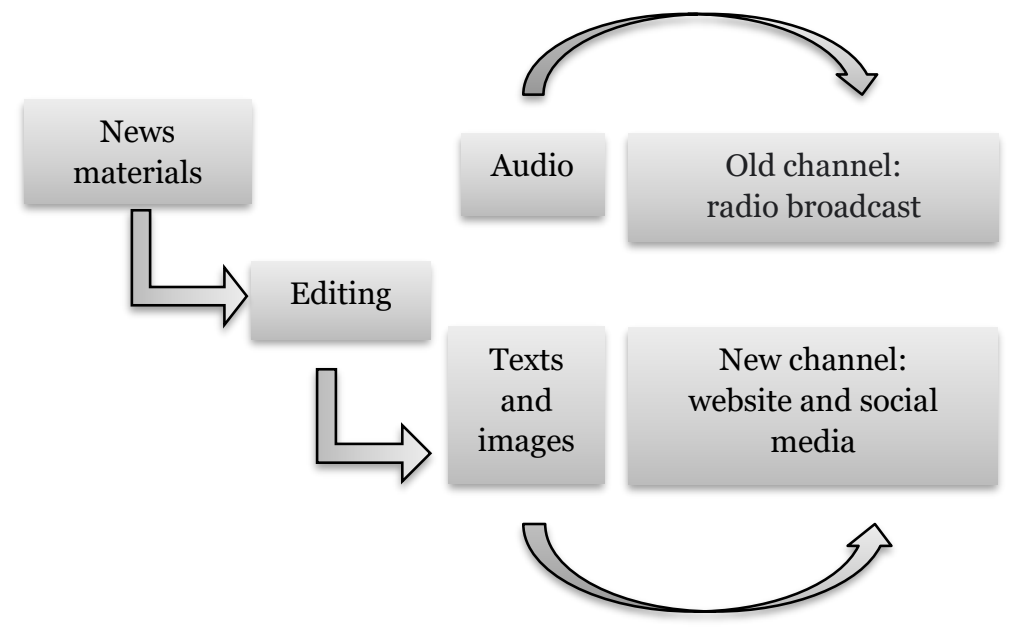

Figure 2. Resource sharing in the convergent newsroom of private radio in Cirebon

This convergent newsroom also shows a technological convergence. Sindangkasih FM, Suara Gratia FM, and Cirebon Radio have combined several different tools and equipment to produce and distribute news, including computers and software (Grant \& Wilkinson, 2009). News production activities have utilized online messaging applications, especially WhatsApp, to communicate between reporter, scriptwriter, program director, and station manager. In broadcasting processes, they have used online media and streaming applications. In marketing activities, they have maximized streaming radio and social media channels. While for promotion to advertisers, they have used internet-based messaging applications and advertising applications such as Ads Mall.

\section{b. Structural convergence}

As mentioned beforehand, structural convergence refers to the management of news coverage and distribution. In the convergence era, we may find a general trend of integrating editor and journalist team works to create one product that can be modified and displayed on different platforms. This happens when a journalist responsible for writing print news can also work with online news reporters to make a television show.

The adaptations of human resource management show that multiskilled journalists, as a central part of the convergent newsrooms, must have the expertise to interview, take pictures, and produce videos for various forms of news: print, broadcast, and online (Dewi, 2012). In Sindangkasih FM, Suara Gratia FM, and Cirebon Radio, a reporter or scriptwriter as news creator is responsible for creating news both for old and new channels. They have to master all skills related to broadcast radio journalism, including collecting, filtering, processing information, scriptwriting, and audio content 
processing. Nowadays, they must be able also to proceed with news for online channels, such as websites and social media, including taking pictures and videos, producing news photos, managing websites and social media.

These phenomena have also changed the coordination styles between the program director or station manager to the reporter or scriptwriter. In the pre-internet era, reporters or scriptwriters had to go through a fixed coordination flow with the program director or station manager, such as a fixed schedule of an editorial meeting. While in the internet era, the planning flow could be done via short messages on online messaging applications.

To carry out activities in a converged newsroom, Fisher (2007) formulated four main roles, one of which is a multiskilled journalist or backpack journal or one-man band. A multiskilled journalist should have multiple expertise to interview, take pictures, photos, videos, for news in various formats: print, broadcast, and online. This study has shown that in addition to mastering all skills related to broadcast radio journalism, reporters and scriptwriters have to be talented to process news for online channels.

\section{c. Interactivity in the convergent journalism}

Pavlik (2001) has differentiated the levels of interactivities in online media. According to this author (Pavlik, 2001), the first dialogue occurs between humans and computer programs. This first level emphasizes the interactivity between users and writers using interactive content provided by online media: e-mail, online graphics, comment fields, likers, and group discussions. Both dialogues occur simultaneously or nearly so, in which response time is no more than a few seconds. This second interactivity emphasizes the interactivity of the users and the writers happening simultaneously. The users will be able to comment on one news directly, and the comments will be read by the author immediately. In the third interactivity, all viewers have some control over what media content they are viewing, such as getting personalized information, enlarging images, and clicking on hyperlinks. This interactivity emphasizes that users have control over online media, so they can easily move from one site to another with existing links (Pavlik, 2001).

In Sindangkasih FM, Suara Gratia FM, Cirebon Radio, interactivity with the audiences happens through several media. First, interaction conducts via telephone. For example, listeners may provide information about specific issues in their local environment via a telephone line during a request program. Second, interactivities happen through social media and websites through giving comments, sharing, and others. For example, when broadcasters publish information containing broadcast activities, listeners 
usually leave their comments about the program or particular issues, which may further become the source for the radio's programs.

These interactivities will in turn help to expand the audiences of the radio. The radio industry has its own strategy to expand the audience market in the era of media convergence. There are four parts of the strategy: enterprise, corporate, business, and functional strategy (Trinoviana, 2017). In order to expand their audiences and advertisers, Sindangkasih FM, Suara Gratia FM, and Cirebon Radio market their programs through conventional and online media. Traditional marketing is done through promotions in the form of spots and adlibs on their broadcast frequency with a certain geographically limited audience. Meanwhile, marketing via online media occurs when promotions through conventional frequency are broadcast on online streaming as well as promotions on social media channels with a broader audience reach.

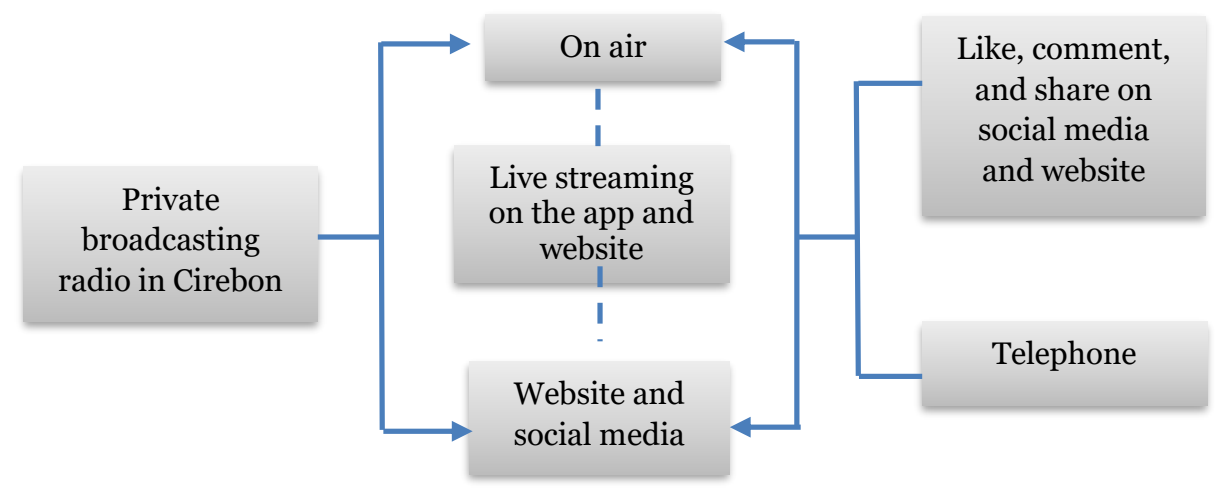

Figure 3. Interactivity in private radio in the convergence era

\section{Conclusion}

Sindangkasih FM, Suara Gratia FM, and Cirebon Radio are transforming themselves towards convergent broadcasting journalism. So far, they have gone through some steps, primarily structural, information coverage, and news presentation or storytelling convergence.

The structural convergence happened at the organizational structure of the radio. As the leader of the broadcast program, the program director or station manager has direct and more fluid coordination with the reporter and scriptwriter as the news creators responsible for news coverage and reports. At the information coverage level, reporters and scriptwriters should manage the news content for frequency broadcasts and new online media, such as websites and social media. Thus, in their news coverage, in addition to conducting observations and interviews, reporters should also take photos or videos. At the level of news presentation, the news is not only broadcast, but also reported on new online channels, such 
as websites and social media. These convergences have changed the practices of editorship towards a more convergent newsroom, including integrating the journalism workflows, applying multiskilled journalism and resource sharing, and using various technological tools. This kind of convergent newsroom has further created interactivity with the audience and expanded the audience reach.

\section{Notes on contributors}

Afiaty Fajriyah Ningrum is working at Mores Strategics. Afiaty was graduated from the Faculty of Communication Science, Universitas Padjadjaran. She has great enthusiasm for journalism and media studies, especially with an ethnographic approach. Afiaty studied the local media ecosystem and alternative journalism in West Java.

Email: afiatysudrajat@gmail.com

Justito Adiprasetio is a lecturer at the Journalism Program, Faculty of Communication Science, Universitas Padjadjaran. He has been teaching contemporary journalism and media studies since 2015. He holds two master's degrees from Gadjah Mada University, in the fields of Cultural and Media Studies, and Communication Studies. His research interests range from issues of misinformation, communication and history, new media, discourse on gender and sexuality, and contemporary journalism. Justito regularly writes in popular media and scientific journals. He has also written a book dealing with gender discourse in Indonesia. Email: justitoadiprasetio@gmail.com 


\section{References}

Adiprasetio, J., \& Wibowo, K. A. (2020). Konvergensi jurnalisme: Reorganisasi, komodifikasi dan eksploitasi. In J. R. Suminar, D. I. Surtikarani, F. Nasir, A. Surahmat, P. N. Fatimah, S. F. Z. Fibaeti, E. R. Juningsih, Sugiyarto, \& Y. Wulandari (Eds.), Komunikasi Organisasi dalam Era Post-Modern (pp.501-509). Unpad Press.

Benkler, Y. (2006). The wealth of networks. Yale University Press.

Berry, R. (2006). Will the iPod kill the radio star? profiling podcasting as radio. Convergence: The International Journal of Research into New Media Technologies, 12(2), 143-162. https://doi.org/10.1177/1354856506066522

Berryman, B. (1999). Converging signals: Digital radio and program associated data. Media International Australia Incorporating Culture and Policy, 91(1), 43-54.

Cwynar, C. (2017). NPR music: Remediation, curation, and National Public Radio in the digital convergence era. Media, Culture \& Society, 39(5), 680-696.

https://doi.org/10.1177/0163443716674362

Dewi, H. K. (2012). Pola dan alur kerja jurnalistik dalam ruang redaksi berkonvergensi (Studi kasus redaksi Bisnis Indonesia). Universitas Indonesia. https://docplayer.info/50211531-Universitasindonesia-pola-dan-alur-kerja-jurnalistik-dalam-ruang-redaksi-berkonvergensi-studi-kasusredaksi-bisnis-indonesia.html

Edmond, M. (2015). All platforms considered: Contemporary radio and transmedia engagement. New Media \& Society, 17(9), 1566-1582. https://doi.org/10.1177/1461444814530245

Erdal, I. J. (2009). Cross-media (Re)production cultures. Convergence: The International Journal of Research into New Media Technologies, 15(2), 215-231. https://doi.org/10.1177/1354856508105231

Fadilah, E., Yudhapramesti, P., \& Aristi, N. (2017). Podcast sebagai alternatif distribusi konten audio. Jurnal Kajian Jurnalisme, 1(1), 90-104. https://doi.org/10.24198/jkj.v1i1.10562

Fisher, H. A. (2007). Developing media managers for convergence. In A. E. Grant \& J. Wilkinson (Eds.), Understanding Media Convergence: The State of the Field (pp.135-150). Oxford University Press.

Gordon, R. (2003). The meanings and implications of convergence. In K. Kawamoto (Ed.), Digital Journalism: Emerging Media and the Changing Horizons of Journalism (pp. 57-73). Rowman \& Littlefield.

https://www.academia.edu/948530/_meanings_and_implications_of_convergence_In_KAW AMOTO_Kevin_ed_Digital_Journalism_Emerging_Media_and_the_Changing_Horizons_of_ Journalism?auto=download

Gould, L. (2009). Beyond media 'Platforms'? Talkback, radio, technolgy and audience. Media International Australia, 131(1), 95-105. https://doi.org/10.1177/1329878X0913100111

Grant, A. E., \& Wilkinson, J. S. (2009). Understanding media convergence. Oxford University Press.

Hacklin, F., Klang, D., \& Baschera, P. (2013). Managing the convergence of industries: Archetypes for successful business models. In Media and Convergence Management (pp. 25-36). Springer Berlin Heidelberg. https://doi.org/10.1007/978-3-642-36163-0_3

Harliantara. (2016). Komunikasi siaran integrasi media konvensional dan internet pada penyiaran radio swasta. Jurnal Komunikasi, 1O(2), 152-168.

https://doi.org/10.20885/komunikasi.vol10.iss2.art4 
Harliantara. (2019). Website pada industri penyiaran radio di Indonesia: Live streaming dan podcasting. Jurnal Studi Komunikasi (Indonesian Journal of Communications Studies), 3(1), 82. https://doi.org/10.25139/jsk.v3i1.983

Hess, T., \& Matt, C. (2013). The internet and the value chains of the media industry. In D. S \& K. M. (Eds.), Media and Convergence Management (pp. 37-55). Springer Berlin Heidelberg. https://doi.org/10.1007/978-3-642-36163-0_4

Jenkins, H. (2001). Convergence? i diverge. Technological Review. https://www.technologyreview.com/2001/o6/o1/235791/convergence-i-diverge/

Jenkins, H. (2008). Convergence culture: Where old and new media collide. NYU Press. https://books.google.co.id/books?id=HZgUCgAAQBAJ

Kaltenbrunner, A., \& Meier, K. (2013). Convergent journalism-Newsrooms, routines, job profiles and training. In S. Diehl \& M. Karmasin (Eds.), Media and Convergence Management (pp. 285298). Springer Berlin Heidelberg. https://doi.org/10.1007/978-3-642-36163-0_19

Markman, K. M. (2012). Doing radio, making friends, and having fun: Exploring the motivations of independent audio podcasters. New Media \& Society, 14(4), 547-565. https://doi.org/10.1177/1461444811420848

Menke, M., Kinnebrock, S., Kretzschmar, S., Aichberger, I., Broersma, M., Hummel, R., Kirchhoff, S., Prandner, D., Ribeiro, N., \& Salaverría, R. (2018). Convergence culture in European newsrooms. Journalism Studies, 19(6), 881-904. https://doi.org/10.1080/1461670X.2016.1232175

Ningrum, A. F., \& Adiprasetio, J. (2021). Cirebon radio: Adaptasi jurnalisme penyiaran lokal di era konvergensi. Jurnal Kajian Jurnalisme, 4(2), 147. https://doi.org/10.24198/jkj.v4i2.27825

Panuju, R. (2018). Konvergensi media dakwah: Studi kasus radio komunitas Ma'dinul Ulum Tulungagung. Jurnal Komunikasi Islam, 7(1), 87-107. https://doi.org/10.15642/jki.2017.7.1.87107

Pavlik, J. V. (2001). Journalism and new media. Columbia University Press. http://cup.columbia.edu/book/journalism-and-new-media/9780231114837

PRSSNI. (2015). Program umum PRSSNI periode 2015-2019. Keputusan Munas XIV PRSSNI.

PRSSNI. (2017). Radio profil PRSSNI Jawa Barat 2017. Pengurus Daerah PRSSNI Jawa Barat.

Quandt, T., \& Singer, J. (2009). Convergence and cross-platform content production. In K. WahlJorgensen \& T. Hanitzsch (Eds.), International Communication Association Handbook Series (pp. 13-146). Routledge. https://openaccess.city.ac.uk/id/eprint/4021/

Rachmaria, L., \& Dewi, Y. R. (2018). Strategi dan praktik konvergensi media pada segmen makarena dalam program sore Bara Harsya sebagai upaya survival radio Delta FM di tengah persaingan industri penyiaran. JIKE : Jurnal Ilmu Komunikasi Efek, 1(2), 233-247. https://doi.org/10.32534/jike.v1i2.160

Rajewsky, I. (2002). Intermedialita. A. Francke Verlag.

Roco, M. C. (2002). Coherence and Divergence of Megatrends in Science and Engineering. Journal of Nanoparticle Research, 4(1), 9-19. https://doi.org/10.1023/A:1020157027792

Sacco, V. (2016). How does social media shape media convergence? The case of journalists covering war and conflict. In Media convergence handbook-Vol. 1: Journalism, broadcasting, and social media aspects of convergence (pp. 363-386). Springer. 
Silverstone, R. (1995). Convergence is a dangerous word. Convergence: The International Journal of Research into New Media Technologies, 1(1), 11-13.

https://doi.org/10.1177/135485659500100102

Spyridou, L.-P., \& Veglis, A. (2016). Convergence and the changing labor of journalism: Towards the 'Super Journalist' paradigm. In Media Convergence Handbook - Vol. 1 (pp. 99-116). Springer Berlin Heidelberg. https://doi.org/10.1007/978-3-642-54484-2_6

Thomasen, B. (2007). Tværmedial kommuniation i flermedie-koncepter. In A. B. Petersen \& S. Rasmussen (Eds.), $\mathrm{Pa}^{\circ}$ tværs af medierne (pp. 41-62). Aarhus: AJOUR forlag.

Trinoviana, A. (2017). Strategi konvergensi radio sebagai upaya perluasan pasar audience dan iklan (Studi kasus pada Swaragama Fm (101.7 Fm), Geronimo Fm (106.1 Fm), dan Prambors Radio (102.2 FM/95.8 FM)). Jurnal Komunikasi, 12(1), 35-50.

https://doi.org/10.20885/komunikasi.vol12.iss1.art3

Yin, R. K. (2006). Studi kasus desain \& metode. Raja Grafindo Persada. 